\title{
Snapshot of photovoltaics - February 2018
}

\author{
Arnulf Jäger-Waldau, ${ }^{\mathrm{a}}$ \\ European Commission, Joint Research Centre (JRC), Directorate C: Energy, Transport and Climate, Energy Efficiency and \\ Renewables Unit, Via E. Fermi 2749, 21027 Ispra, VA, Italy
}

Received: 9 February 2018 / Received in final form: 27 February 2018 / Accepted: 28 February 2018

\begin{abstract}
Solar photovoltaic electricity generation is the fastest growing power generation source world-wide. The significant cost reduction of solar PV over the last decade, and the zero fuel cost volatility have increased the attractiveness. In 2017, the newly installed solar PV power of over $90 \mathrm{GW}$ was more than all the world-wide cumulative installed PV capacity until the mid of 2012. China was again the main driver behind this strong growth with more than $50 \mathrm{GW}$ of annual installations in 2017. Apart from the electricity sector, renewable energy sources for the generation of heat and environmental friendly synthetic-fuels for the transport sector will become more and more important in the future.
\end{abstract}

Keywords: renewable energies / photovoltaic / energy challenge / policy options / technological development / market development

\section{Introduction}

The 23rd session of the Conference of the Parties (COP22) to the United Nations Framework Convention on Climate Change (UNFCCC) took place in Bonn, Germany from 6 to 17 November 2017. It was the second session after the Paris Agreement, which aims to keep the maximum global average temperature rise as close as possible to $1.5^{\circ} \mathrm{C}$, entered into force on 4 November 2016.

There is general consensus that the Nationally Determined Contributions (NDC's) proposed by each country are only a stepping stone on the way to realise the goals of the Paris Agreement. Therefore, a mandatory cycle of NDC's was established where enhanced ambitions have to be submitted every five years from 2020 onwards.

With respect to the future market development of renewable power and solar photovoltaics in particular, the formal launch of an alliance of nations and states committed to moving the world from burning coal to cleaner power sources was a promising sign at COP23. In their founding declaration, the Powering Past Coal Alliance states: "To meet the Paris Agreement, analysis shows that coal phase-out is needed no later than by 2030 in the OECD and EU28, and no later than by 2050 in the rest of the world". As of 12 December 2017, the Alliance had already more than 50 members with over 30 countries and

\footnotetext{
* e-mail: Arnulf.jaeger-waldau@ec.europa.eu

${ }^{a}$ The scientific output expressed is based on the current information available to the author, and does not imply a policy position of the European Commission.
}

states, which account for approximately $55 \mathrm{GW}$ of coal fired power generation capacity [1]. To substitute this generation capacity in the respective countries about $275 \mathrm{GW}$ of solar PV systems are required.

Decarbonisation of our energy supply is an important component to achieve the targets, because $65 \%$ of the world's current $\mathrm{CO}_{2}$ emissions are due to burning fossil fuels. In $2014,81 \%$ of our total primary energy supply depended on burning fossil fuels, namely $29 \%$ coal, $31 \%$ oil and $21 \%$ natural gas [2]. In terms of final energy consumption electricity only accounted for $18.1 \%$, but was responsible for $35.2 \%$ of the total $\mathrm{CO}_{2}$ emissions $[2,3]$.

Photovoltaics (PV) is one of the key technology options for implementing the shift to a decarbonised energy supply and can be deployed in a modular way almost everywhere on this planet. Solar resources across the world are abundant and cannot be monopolised by one country.

\section{PV solar cell production}

Production data for the global cell production ${ }^{1}$ in 2017 vary between 94 and $100 \mathrm{GW}$ and estimates for 2018 are in the 105-115 GW range. The significant uncertainty in this data is due to the highly competitive market environment, as well as the fact that some companies report shipment

\footnotetext{
${ }^{1}$ Solar cell production capacities mean: in the case of wafer silicon based solar cells, only the cells; in the case of thin-films, the complete integrated module; only those companies which actually produce the active circuit (solar cell) are counted; companies which purchase these circuits and make cells are not counted.
} 


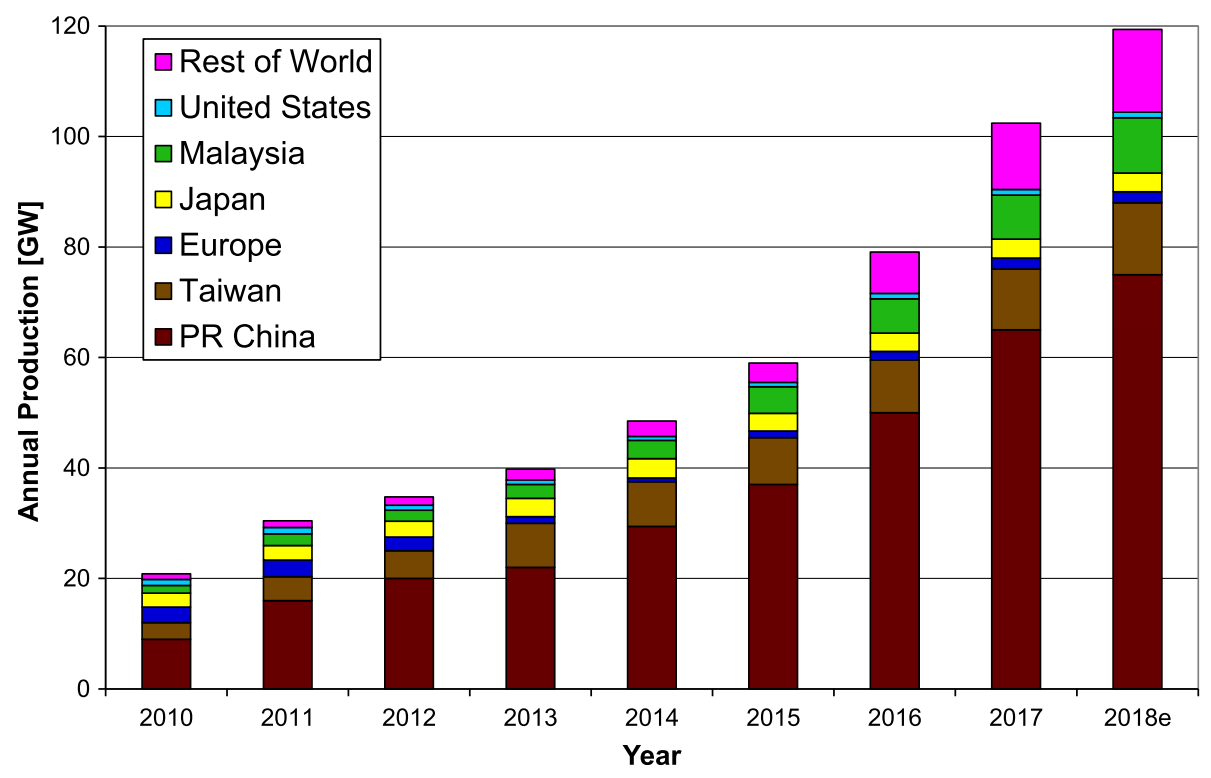

Fig. 1. World PV Cell/Module Production from 2010 to 2018.

figures, while others report sales and again others report production figures. After China overtook Germany in terms of cumulative installed nominal capacity in 2015, Japan followed in 2016 and the USA in early 2017.

The data presented, collected from stock market reports of listed companies, market reports and colleagues, were compared to various data sources and thus led to an estimate of $97 \mathrm{GW}$ (Fig. 1), representing an increase of about $26 \%$ compared to 2016 and another increase of about $15 \%$ is expected for 2018 .

Uncertainties in Production Statistics:

- only a limited number of companies report production figures for solar cells or thin film modules. Often the production of "solar products" is reported, without a differentiation between wafers, cells or modules;

- shipment figures can include products from stock, already produced in the previous year;

- some companies report shipments of "solar products" without a differentiation between wafers, cells or modules; - the increasing trend towards Original Equipment Manufacturing (OEM) increases the potential of double counts.

The production volume in 2017 was about 320 times that of 2000 , with a compound annual growth rate (CAGR) of over $40 \%$. After a rapid increase of the annual production in China and Taiwan since 2006 a new trend emerged in 2014 to increase production capacities in other Asian countries like India, Malaysia, the Philippines or Vietnam. It is worthwhile to note that the largest share of these investments is done by Chinese companies. Another trend in the PV industry was the rapid increase in OEM volumes since 2011, which allowed larger companies to significantly increase their shipment volumes without adding new capacity of their own.

The overcapacity in the solar industry, which was first triggered by massive capacity expansions between 2007 and 2011, has only gradually eased. There is a continuing price pressure along the value chain. In addition, the volatility of the spot market prices has increased considerably.

The rapid price declines for solar system hardware put all solar companies under enormous pressure and access to fresh capital for growth was and still is key to survival. Consolidation in the PV manufacturing industry has led to the closure or takeover of a significant number of companies since 2009 [4]. Despite those bankruptcies and companies with idling production lines or even permanent closures of their production facilities, the number of new entrants to the field, notably large semiconductor, construction or energy-related companies, is remarkable and makes a reasonable forecast for future capacity developments very speculative.

Since the beginning of 2014, the announcements of new capacity expansions have significantly increased. In the first three quarters of 2017, about $40 \mathrm{GW}$ of new manufacturing capacity for crystalline silicon solar cells $(>37 \mathrm{GW})$ and thin film solar cells (approx. 2.7 GW), was announced. However, there is a huge discrepancy between these announcements and confirmed equipment orders. In addition the ongoing cost pressure and the drive to modules with higher efficiencies, makes it is obvious, that older production lines have to be upgraded or substituted with manufacturing capacities capable to produce these higher efficient solar cells. Therefore, the overall net capacity increase of solar cells will be much lower than the announcements imply.

The general trend still is pointing in the direction of more capacity announcements fuelled by the hope of an annual $50 \mathrm{GW}+$ market in China and new markets, especially in India, the Middle East and South America. The latest trend in the solar photovoltaic manufacturing industry is the trend to accelerate the move to the manufacturing 4.0 concept. The main driver is the opportunity for further cost reduction using fully automated and remotely controlled manufacturing lines. This 


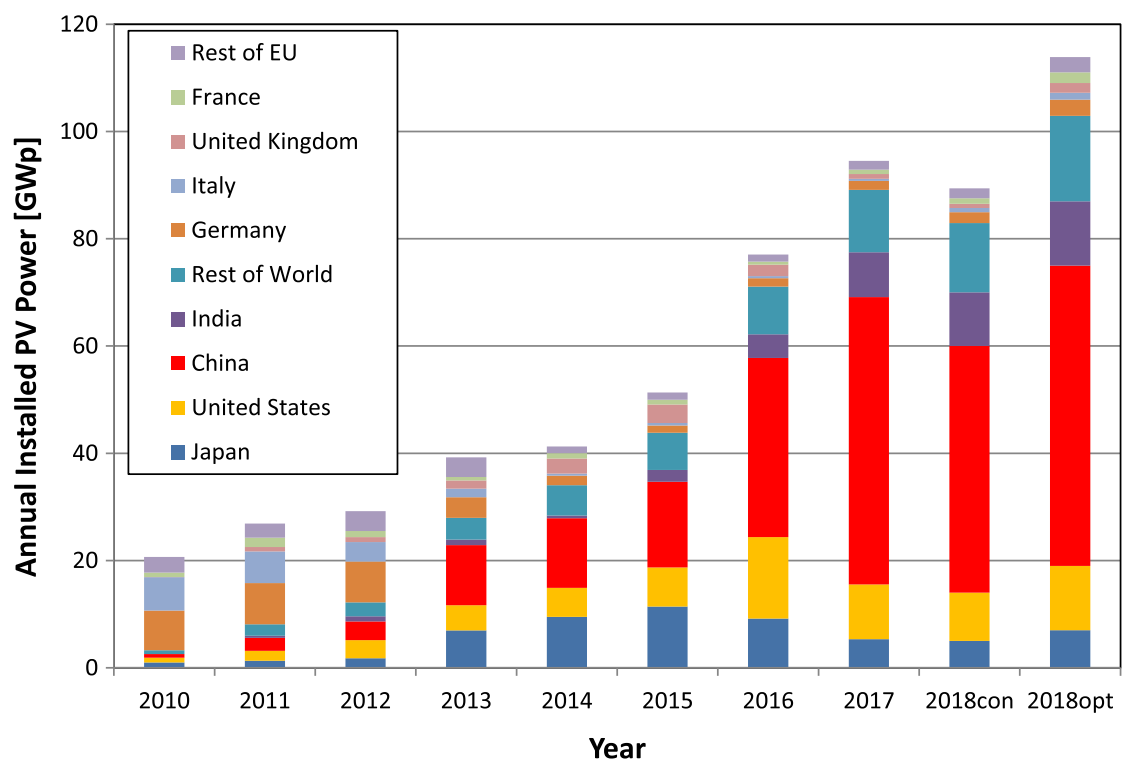

Fig. 2. Annual photovoltaic installations from 2010 to 2018 (data source: $[12,13,14]$ and own analysis).

development together with other technological innovation has a negative impacted to PV manufacturers with older production equipment. For example, polysilicon equipment with annual production capacity of 10,000 tons needed an investment of USD 1.5 billion in 2006-2007, but capital expenditure (CAPEX) costs for such equipment with the same capacity have dropped by $90 \%$ in 2017 . In addition, new manufacturing plants for polysilicon and wafer production are new set up in the country's northwestern and southwestern regions where power prices can be $75-90 \%$ lower than in the Chinese costal regions [5]. Due to the fact that electricity still accounts for about 20 and $40 \%$ of wafer and polysilicon production costs this move leads to a significant reduction of the respective production costs.

Overall, the number of jobs in solar cell and module manufacturing is likely to decrease despite massive capacity expansions, whereas the overall job number especially in the downstream segment will significantly increase due to an increasing market.

\section{Solar PV electricity generation and markets}

In January 2018, the world-wide average system price for residential systems with installation, but without permitting or connection costs, was given with 1.52 USD/ $\mathrm{Wp}(1.22 \mathrm{EUR} / \mathrm{Wp})$ ranging between $1.23 \mathrm{USD} / \mathrm{Wp}$ (1.05 EUR/Wp) in Europe and up to $1.73 \mathrm{USD} / \mathrm{Wp}$ (1.38 EUR/Wp) in some other cases [6]. For commercial systems the range was given with $0.76 \mathrm{USD} / \mathrm{Wp}$ (0.61 EUR/Wp)-1.57 USD/Wp (1.26 EUR/Wp). For 2017, the total CAPEX for a project, which includes projecting and permitting costs, the range for utility $\mathrm{PV}$ systems was given between for the 5 th percentile and 95 th percentile range as USD 898 and 3754 per $\mathrm{kWp}$ with a weighted average of USD 1388 per $\mathrm{kWp}$ [7]. The resulting levelised costs of electricity (LCOE) in addition depend on the solar radiation, fixed operation and maintenance (O\&M) costs, cost of debt and the return on equity expectations, which differ from country to country. The overall range for LCOE from PV systems realised in 2017 was between 37 USD/MWh and 308 USD/MWh, whereas the lower end represents the utility scale projects and the higher end residential rooftop projects [8].

Since 2009, the price for power purchase agreements (PPA) have decreased by almost $70 \%$ reaching 50 USD/ MWh in sunnier regions of the world with reasonable financing costs. 2017 again saw a number of record breaking PPA contracts and bids below USD 20/MWh and a new low was observed with a bid of SAR 66.97 or USD 17.86 per MWh by Masdar and EDF for a $300 \mathrm{MW}$ project in Saudi Arabia in October 2017. The following month saw bids for $3040 \mathrm{GWh}$ of solar photovoltaic electricity at an average price of USD 20.8 per MWh. The winning consortia have to start deleivering electricity at the latest on 1 January 2020. These very low bids and PPAs in the Chile, Mexico and Arabia are only possible through a combination of excellent solar resource, high debt shares and very low debt costs as well as the fact that some tariffs are indexed to inflation and the start of electricity delivery can be as late as 2020 .

2017 saw an $18 \%$ increase of total global investment in solar energy from USD 137 billion to USD 161 billion. At the same time, the annual installed capacity of new photovoltaic power increased by more than $25 \%$ to over 94 GW (Fig. 2).

Market predictions for the $2018 \mathrm{PV}$ market vary between 94 and 111 GW $[9,10]$ with a consensus value in the $100 \mathrm{GW}$ range. With a similar growth rate expected for the following years, this is exceeding even the accelerated case scenario of almost $580 \mathrm{GW}$ solar PV capacity additions between 2017 and 2022 in the IEA Renewables 2017 Report [11]. 


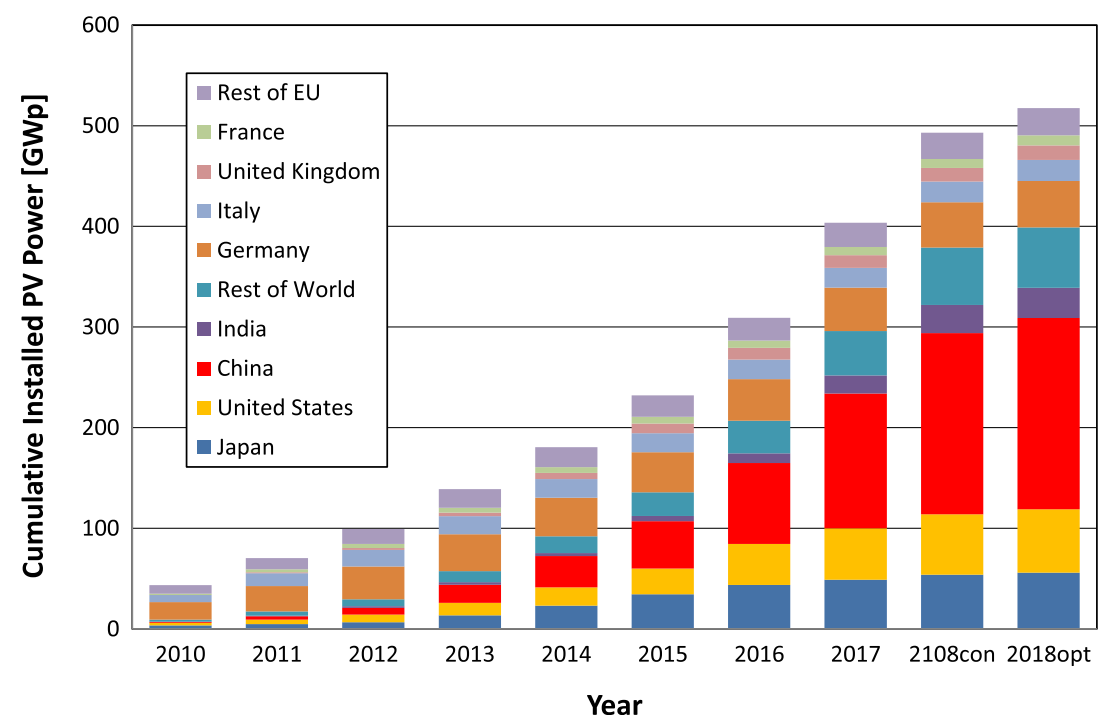

Fig. 3. Cumulative Photovoltaic Installations from 2010 to 2018 (data source: $[12,13,14]$ and own analysis).

This represents mostly the grid connected photovoltaic market. To what extent the off-grid and consumer product markets are included is not clear, but it is believed that a substantial part of these markets are not accounted for as it is very difficult to track them. However, with increasing market size these segments become smaller and smaller in percentage terms.

Uncertainties in Market Statistics:

- not all countries report standard nominal power capacity for solar PV systems (DC - Wp under standard test conditions), but especially for larger scale system the utility peak AC capacity relevant for the transmission operator;

- some statistics only count the capacity which is actually connected or commissioned in the respective year for the annual statistics, irrespectively when it was actually installed. This can lead to short term differences in which year the installations are counted. This can lead to differences in the annual statistics, but levels out in the long-run, if no double counting occurs. E.g.: (1) in Italy about $3.5 \mathrm{GW}$ of solar PV systems were reported under the second conto energia and installed in 2010, but only connected in 2011. (2) The construction period of some large solar farms spread over two or more years. Depending on the regulations - whether or not the installation can be connected to the grid in phases and whether or not it can be commissioned in phases, the capacity count is different;

- some countries donot have official statistics on the capacity of solar PV system installations or sales statistics of the relevant components.

With a cumulative installed capacity of over $130 \mathrm{GW}$ China represents about one third of the global installed PV capacity followed by the European Union with about $26 \%$ or $107 \mathrm{GW}$ of the total $400 \mathrm{GW}$ solar photovoltaic electricity generation capacity at the end of 2017 (Fig. 3).

The Asia \& Pacific Region saw again an acceleration of photovoltaic electricity system installations driven by China and India. In addition, countries such as the Gulf
States, Indonesia, Malaysia, Pakistan, South Korea, Taiwan, Thailand, The Philippines and Vietnam continue a very positive upward trend, thanks to increasing governmental commitment towards the promotion of solar energy, the creation of sustainable cities and the substantial decrease of PV system prices.

In 2017 about $75 \mathrm{GW}$ of new PV electricity generation systems were installed in the region almost a 10 fold increase compared to the $8.2 \mathrm{GW}$ in 2012 . The largest market was China with over $50 \mathrm{GW}$ followed by India with about $7.5 \mathrm{GW}$ and Japan with about $7 \mathrm{GW}$. For 2018 a moderate market increase could be possible in the optimistic scenario.

European Union: Market conditions for photovoltaics differ substantially from country to country. This is due to different energy policies and public support programmes for renewable energies and especially photovoltaics, as well as the varying grades of liberalisation of domestic electricity markets [4]. After a twentyfold increase of solar photovoltaic electricity generation capacity between 2001 and 2011, the capacity of newly installed PV systems decreased continuously from the peak in 2011 with almost $19 \mathrm{GW}$ of new installations to about $5.2 \mathrm{GW}$ in 2017. After five years of limited new PV power installations, 2018, 19 and 20 will bring some change. In July 2017, the Spanish Ministry for Energy and Tourism announced the winners of the second renewable energy auction in 2017 and solar photovoltaic power projects had won $3.9 \mathrm{GW}_{\mathrm{AC}}$ in this auction [15]. The winning consortia have to connect the systems before the 1st January 2020. In addition France tendered about 1.5 GW of PV capacity, of which most should be installed in 2018. Therefore, an increase of PV installations up to $8 \mathrm{GW}$ is possible in 2018.

The legal framework for the overall increase of renewable energy sources was set with the Directive 2009/28/EC, and in their National Renewable Energy Action Plans (NREAPs), the Member States have set specific photovoltaic solar energy targets, adding up to $84.5 \mathrm{GW}$ in 2020 . This target was already exceeded in 2014 but no new targets for solar energy have been set yet. 
Table 1. Evolution of the cumulative solar electrical capacities until $2050[15,16,17]$.

\begin{tabular}{llllll}
\hline \multicolumn{1}{c}{ Year } & $2017[\mathrm{GW}]$ & $2020[\mathrm{GW}]$ & $2025[\mathrm{GW}]$ & $2030[\mathrm{GW}]$ & $2040[\mathrm{GW}]$ \\
\hline Actual Installations & $\mathbf{4 0 3}$ & - & - & - & - \\
Greenpeace (reference scenario) & - & 332 & 413 & 494 & 635 \\
Greenpeace (advanced [r]evolution scenario) & - & 844 & 2000 & 3725 & 6678 \\
IEA New Policy Scenario 2016 & - & 481 & 715 & 949 & 1405 \\
IEA 450 ppm Scenario 2016 & - & 517 & 814 & 1278 & 2108 \\
IEA New Policy Scenario 2017 & - & 498 & 939 & 1295 & 2067 \\
IEA Sustainable Development Scenario 2017 $^{*}$ & - & 545 & 1188 & 1846 & 3246 \\
\hline
\end{tabular}

2025 value is extrapolated, as only 2020 and 2030 values are given.

In the process of the current recast of the Renewable Energy Directive, the European Parliament voted in January 2018 for a binding target of $35 \%$ renewable energies by 2030. Now, the Member States have to decide on their position and whether or not they support this target. If the Council agrees, the European Commission will have to draft a new Directive to make sure the target can and will be reached.

To reach the $35 \%$ RES target, electricity generation from Renewable Energy Resources has to reach 1,800$2,000 \mathrm{TWh}$ in 2030 , more than twice the value in 2016 . The largest share of this renewable energy, about 1,300 TWh will have to be supplied by solar and wind power. Compared to the electricity production of about $410 \mathrm{TWh}$ (approx. $300 \mathrm{TWh}$ wind and $110 \mathrm{TWh} \mathrm{PV}$ ) in 2016 an increase by more than 3 times is needed.

North America: In 2017, the new installed PV capacity in the USA expected to be between 11 and $12 \mathrm{GW}$ and reached a cumulative PV capacity of over $51 \mathrm{GW}$. Utility PV installations again were the largest segment with about half of the new installed capacity in 2017. For 2018 a flat or slightly decrease is expected. During the 4Q of 2017 about $4 \mathrm{GW}$ of contracted PPA projects were under construction and the total PV project pipeline in the USA slightly decreased and is now in the range of $49 \mathrm{GW}$ at different development and planning stages.

Many State and Federal policies and programmes exist and one of the most comprehensive databases about the different support schemes in the US is maintained by the Solar Centre of the State University of North Carolina. The Database of State Incentives for Renewable Energy (DSIRE) is a comprehensive source of information on State, local, utility, and selected Federal incentives that promote renewable energy. All the different support schemes are described therein and it is highly recommended to visit the DSIRE web-site http://www.dsireusa.org and the corresponding interactive tables and maps for details.

\section{Conclusions}

The photovoltaic industry has changed dramatically over the last few years. China has become the major manufacturing place followed by Taiwan and Malaysia.
Looking at photovoltaics it is important to remember, that the PV industry is more than just cell and module manufacturing and to grasp the whole picture one has to look at the whole PV value chain. Besides the information in this paper about the manufacturing of solar cells, the whole upstream industry (e.g. materials, polysilicon production, equipment manufacturing), as well as the downstream industry (e.g. inverters, BOS components, system development, installations) has to be looked at as well.

According to investment analysts and industry prognoses, solar energy will continue to grow at high rates in the coming years. The different PV industry associations, as well as Greenpeace, the European Renewable Energy Council (EREC) and the International Energy Agency, have developed new scenarios for the future growth of PV systems. Table 1 shows the different scenarios of the Greenpeace/EREC study, and the 2016 and 2017 IEA World Energy Outlook scenarios. It is interesting to note that the predicted PV capacity in the IEA scenarios has significantly increased from 2016 to 2017 . With forecasted new installations between 251 and $270 \mathrm{GW}$ from 2017 to 2019 and annual installations to exceed 100 GW by 2020 , even the Greenpeace advanced revolution scenario for 2020 no longer seems like fiction [16].

With worldwide over $400 \mathrm{GW}$ cumulative installed photovoltaic electricity generation capacity installed by the end of 2017, photovoltaics still is a small contributor to the electricity supply with a little of $2 \%$, but its importance for our future energy mix is now acknowledged.

\section{References}

1. Powering Past Coal Alliance, https://www.gov.uk/ government/uploads/system/uploads/attachment_data/ file/666736/Final_Declaration_PPCA_111217.pdf (2017), accessed on 12 January $201 \overline{8}$

2. International Energy Agency, Key world energy statistics 2016 (2016)

3. International Energy Agency, Emissions per $\mathrm{kWh}$ of electricity and heat output (Edition 2016), IEA CO $\mathrm{CO}_{2}$ emissions from fuel combustion statistics (database). DOI: http://dx.doi.org/ 10.1787/3cfe0c04-en, accessed on 12 January 2018 
4. A. Jäger-Waldau, PV Status Report 2017, Publications Office of the European Union, ISBN 978-92-79-74072-5 (print)

5. N. Huang, A. Hwang, Solar wafer production to see overcapacity by year-end 2018 DIGITIMES (2018)

6. PVinsights, PVinsights.com, accessed on 25 January 2018

7. International Renewable Energy Agency (IRENA), Renewable power generation costs in 2017 (2018)

8. Lazard, Lazard's levelised cost of energy analysis - Version 11.0, November 2017

9. Bloomberg New Energy Finance, 4Q 2017 Global PV Market Outlook, 17 November 2017

10. IHS, PV Demand Tracker Q4 2017, 14 December 2017

11. International Energy Agency, in Renewables 2017- Analysis and Forecasts to 2022, p. 185, https://www.oecd-ilibrary. org/energy/renewables-2017_re_mar-2017-en
12. European Photovoltaic Industry Association, Global Market Outlook for Photovoltaics 2014-2018 (EPIA, 2014)

13. IEA PVPS, Snapshots of Global PV Markets and Trend Reports

14. EurObserv'Er, Photovoltaic Barometer, Systèmes Solaires, le journal du photovoltaïque 5, 144 (2011)

15. International Energy Agency, World energy outlook 2016 (IEA, 2016), ISBN 978-92-64-26495-3

16. Greenpeace International, European Renewable Energy Council (EREC), Global Wind Energy Council (GWEC), Energy [r] evolution, 5th edition 2015 world energy scenario, October 2015, http://www.greenpeace.org/international/ en/publications/Campaign-reports/Climate-Reports/Ener gy-Revolution-2015 (Accessed on 12 January 2018)

17. International Energy Agency, World energy outlook 2017 (IEA, 2017), ISBN 978-92-64-28230-8

Cite this article as: Arnulf Jäger-Waldau, Snapshot of photovoltaics - February 2018, EPJ Photovoltaics 9, 6 (2018) 